DOI: https://doi.org/10.24164/prosiding.v3i1.15

\title{
MELACAK JEJAK FITUR PARIT KUNO MASYARAKAT LAMPUNG: JEJAK MIGRASI AUSTRONESIA JALUR BARAT?
}

\author{
Tracing of a The Feature Lampongese Ancient Drain: \\ The Western Route of Austronesian Migration?
}

\author{
Rusyanti, Nanang Saptono, Endang Widyastuti \\ Balai Arkeologi Jawa Barat \\ Jalan Raya Cinunuk KM.17 Cileunyi Kabupaten Bandung 40623 \\ E-mail: rusyanti08@gmail.com
}

\begin{abstract}
Since 1995, the ancient settlement sites were found in the region of Lampung occupied in the watershed areas (DAS). The research results up to the year of 2018 in West Lampung found a consistent pattern to the emergence of ancient features assumed as ancient moat or trenches. The traces of ancient moat or trench features have not been intensively researched and still leave questions about the ins and outs. The comparison study with similar sites in DAS Way Sekampung also found trenches both in natural and artificial formed. In macro comparison, the trench occupies the topography of different regions, the highlands and the lowlands. The temporary observations of the pattern of trenching settlements have found that the dominance of natural trench formations was discovered in mountainous regions (highland) and on the active fault, while the artificial moats emerged in lowland and floodplain-prone areas. The temporary assumption is made that this moat is a form of adaptation to the environment. In addition to Lampung, the existence of a moat site was also found in Thailand in the period $500 \mathrm{BCE}-600 \mathrm{AD}$. It gave rise to the alleged linkage of the surrounding moats as the migration trail brought by the western Austronesian speakers since the Prehistoric period.
\end{abstract}

Keywords: moat, trench, ancient settlement, Lampung, Austonesia.

\begin{abstract}
AbSTRAK
Sejak tahun 1995, situs-situs permukiman kuno ditemukan di wilayah Lampung menempati daerah-daerah aliran sungai (DAS). Hasil penelitian hingga tahun 2018 di Lampung Barat menemukan pola yang konsisten terhadap munculnya jejak fitur yang disebut sebagai parit atau siring. Jejak fitur parit hingga saat ini belum diteliti secara intensif dan masih menyisakan pertanyaan tentang seluk beluknya. Perbandingan studi pustaka dengan situs-situs sejenis di DAS Way Sekampung juga mendapati parit-parit baik alami maupun buatan. Secara makro perbandingan parit tersebut menempati topografi wilayah yang berbeda, yaitu di dataran tinggi dan dataran rendah. Hasil pengamatan sementara terhadap pola sebaran permukiman berparit mendapati dominasi bentukan parit alami ditemukan di wilayah pegunungan dan pada jalur sesar, sedangkan parit buatan muncul pada wilayah dataran rendah rawan banjir. Asumsi sementara parit dibuat sebagai bentuk adaptasi terhadap lingkungan. Selain di Lampung, keberadaan situs berparit juga ditemukan di Thailand pada periode 500 SM-600 AD hal tersebut memunculkan dugaan adanya keterkaitan perilaku pembuatan parit keliling sebagai jejak migrasi yang dibawa oleh penutur Austronesia jalur barat sebelum 400 tahun yang lalu.
\end{abstract}

Kata kunci: Parit, fitur, permukiman kuno, Lampung, Austronesia. 


\section{PENDAHULUAN}

$\mathrm{L}$ ampung merupakan wilayah di ujung

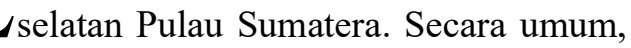
topografi wilayah Lampung bagian barat hingga tenggara berupa perbukitan dan bagian tengah dan timur berupa daratan alluvial dan rawa-rawa. Daerah Lampung dialiri oleh empat sungai utama dari Barat ke Selatan, yaitu Way Semangka, Way Seputih, Way Tulang bawang dan Way Sekampung. Berdasarkan data arkelogis, di tepian sungai-sungai itu banyak ditemukan permukiman kuno. Secara umum, tipologi bentuk permukiman disekitar aliran sungai tersebut seperti di Way Tulang Bawang dan Way Sekampung memiliki kemiripan, yaitu berupa benteng tanah dengan dan tanpa parit (Saptono, 2000:144-166; Laili, 2007: 8189; Laili, 2008:31-44; R.r Triwurjani, 2010: 570-575) sedangkan di Way Seputih data permukiman yang ada berupa perkampungan yang sudah memasuki masa pengaruh Islam (abad 17 M) (Sarjiyanto, 2007: 1-16).

Di aliran anak sungai Way Semangka, yaitu di Way Rubok yang mengalir di wilayah Lampung Barat, ditemukan delapan lokasi yang diduga sebagai permukiman kuno yang tersebar di empat desa. Kedelapan situs tersebut, yaitu Pulau Pinang, Tanjung Raya, Hujung Langit, Kehidupan, Batu Putih, Negeri Ratu, Batu Raja, dan Kurungan Aji. Dua situs diantaranya, yaitu di Tanjung Raya dan Hujung Langit terdapat Prasasti dari Abad ke-10 M beraksara Jawa Kuno bahasa Melayu Kuno, yaitu Prasasti Tanjung Raya 1 \& 2, dan Prasasti Hujung Langit (Rusyanti, 2014).

Dalam beberapa kali survei telah dilakukan penggambaran denah permukiman. Denah-denah permukiman tersebut berupa petak-petak yang dibatasi dengan bentukanbentukan lahan berupa saluran-saluran. Bentukan lahan berupa saluran-saluran tersebut berada di tengah atau mengelilingi denah permukiman dengan ukuran yang bervariasi. Masyarakat sekitar menyebutnya dengan parit. Keberadaan parit-parit tersebut diketahui membagi lahan situs ke dalam beberapa bagian. Apa fungsi dan mengapa parit tersebut dibuat belum diketahui kaitannya dengan keberadaan situs. Tulisan ini merupakan eksplorasi awal tentang keberadaan parit-parit kuno tersebut yang seringkali ditemukan di situs-situs permukiman di Lampung. Dugaan sementara, bentuk-bentuk parit tersebut juga mengingatkan pada budaya-budaya yang ada di nusantara dengan pendahulunya yang berasal dari Taiwan dan China daratan. Penelusuran ini selanjutnya dapat mengantarkan kepada pemahaman terhadap pengungkapan konsepsi alam pikir manusia dalam hal pengelolaan tata lingkungan di masa lampau.

\section{PEMBAHASAN}

Fokus penelusuran mengenai keberadan parit-parit kuno di Lampung dalam tulisan ini berawal dari pola yang teramati di Lampung Barat. Terdapat 5 (lima) lokasi permukiman yang terindikasi memiliki parit keliling, yaitu (1) Situs Tanjung Raya, (2) Situs Hujung Langit, (3) Situs Pulau Pinang, (4) Situs Kehidupan (1 dan 2), dan (5) Situs Sukarame (Batu Raja, Punjung, Puncak, dan Negeri Ratu). Kronologi situs-situs tersebut diperoleh data kisaran $10 \mathrm{M}$ menurut data prasasti (Damais, 1995) dan 10-19 M, berdasarkan analisis keramik (Widyastuti, 2010; 2011). Berikut deskripsi mengenai situs-situs berparit tersebut.

\section{Situs Tanjung Raya}

Situs Tanjung Raya terletak di Desa Tanjung Raya, Kecamatan Sukau. Situs dikenal dengan sebutan pepulau atau Charmemung (pulau menggantung). 
Situs Tanjung Raya terkenal dengan keberadaan Prasasti Tanjung Raya 1 (batu datar), dan Tanjung Raya 2 (batu tegak).

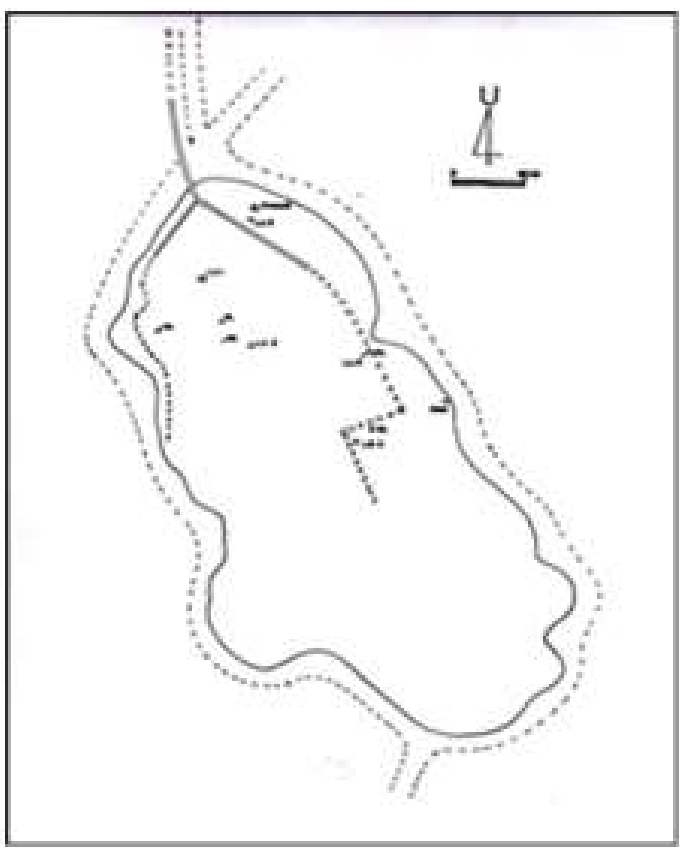

Gambar 1. Denah Situs Tanjung Raya (Sumber: Dokumentasi Balai Arkeologi Jawa Barat, 2012).

Situs Tanjung Raya muncul pada publikasi L.C.H Damais dan N.J. Krom tahun 1995 menyebutkan bahwa Prasati Tanjung Raya beraksara Jawa Kuno, Bahasa Melayu Kuno. Prasasti Tanjung Raya 1, berupa batu datar terdapat goresan yang sudah aus dan tidak terbaca, kemungkinan berasal dari abad ke-10 M. Sedangkan Prasasti Tanjung Raya 2 berupa batu tegak berbunyi "batu pahat", kemungkinan berasal dari abad ke-14 M (Damais, 1995). Di situs ini terdapat sebaran fragmen keramik, tembikar dan temuan dua arca dari batu tufa di tebing situs. Jejak Parit kuno terlihat mengelilingi situs dengan lebar dan kedalaman 20-40-meter dan ditumbuhi semak serta pohon bambu (Gambar 1). Pada dasar parit (siring) berupa kolam yang difungsikan sebagai sawah dan kolam ikan (Rusyanti, 2012).

\section{Situs Hujung Langit}

Situs Hujung terletak di Desa Harakuning Jaya, Kecamatan Sukau. Situs dikenal juga dengan keberadaan Prasasti Hujung Langit (919 M) yang pertama kali dilaporkan oleh tim Pegawai Dinas Topografi pada tahun 1912 kemudian disusul pembacaan oleh L.C Damais pada tahun 1954-1957, de Casparis, dan Krom. Prasasti Hujung Langit dikeluarkan oleh Punku Haji Yuwaraja Sri Haridewa untuk keperluan bangunan suci wihara di daerah Hujung Langit (Damais, 1995: 27-45).

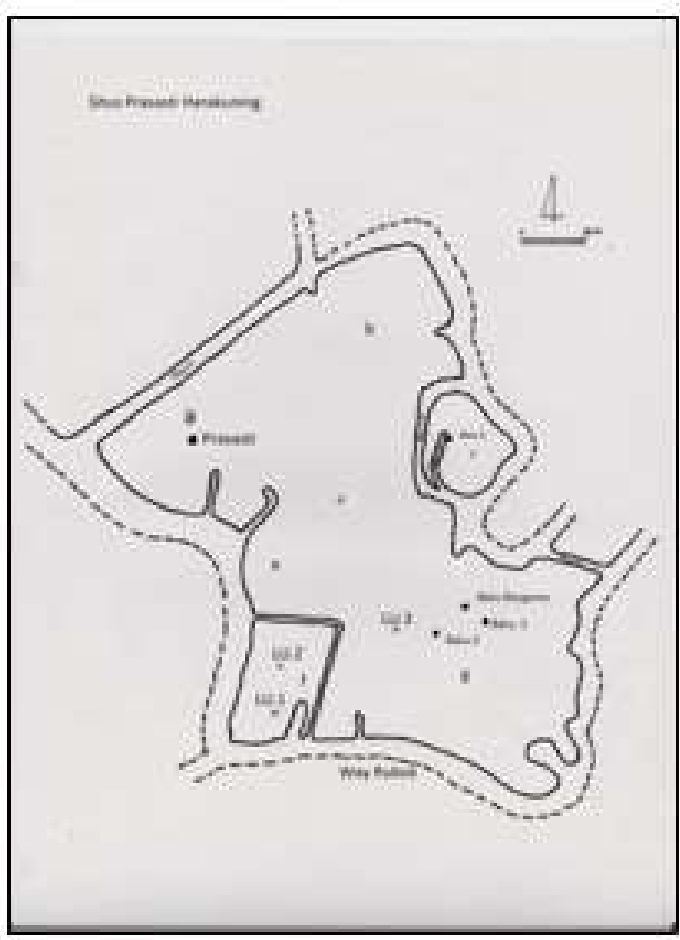

Gambar 2. Denah Situs Hujung Langit dan paritnya yang saat ini berfungsi sebagai kolam (Sumber: Dokumentasi Balai Arkeologi Jawa Barat, 2013 \& 2018). 
Di situs ini ditemukan Prasasti, sebaran fragmen tembikar, keramik, batu bergores arca/figurin, dan batu datar. Pada tahun 1995, Balar Jabar melakukan ekskavasi dan menyingkap tatanan batuan yang diduga merupakan bagian dari struktur bangunan. Lingkungan situs berada pada morfologi bergelombang dan tanah yang tertutupi material vulkanik dari formasi Ranau (Agus., et.al., 1995). Situs diduga merupakan permukiman masa klasik abad $10 \mathrm{M}$ dan berlanjut sesudahnya. Jejak parit sama dengan Tanjung Raya dengan kedalaman dan lebar 20-40 meter, ditumbuhi semak dan pohon bambu serta difungsikan saat ini sebagai kolam. (Gambar 2). Hasil overlay peta geologi Lampung Barat menunjukkan lokasi situs berada pada jejak patahan/ sesar (Rusyanti, Purwoarminta, Krama, \& Widyastuti, 2018)

\section{Situs Pulau Pinang}

Situs Pulau Pinang terletak di Dusun Suka Menanti Kecamatan Balik Bukit. Situs berupa lahan pertanian yang dikelilingi oleh siring dan di sebelah utaranya terdapat makam Keramat Batin Sakuan. Luas lahan sekitar 1 ha. Pada permukaan lahan banyak ditemukan sebaran fragmen keramik, tembikar. Di utara situs terdapat satu bukit kecil yang dikelilingi siring bernama Keramat Batin Sakuan. Jejak parit di situs ini telah terganggu oleh olah lahan pertanian berupa bentukan lahan yang menjorok ke bawah yang membagi dua petak lahan diduga merupakan kontur alami berupa tanah menurun.

\section{Situs Kehidupan 1 dan 2}

Situs Kehidupan terletak di Dusun Suka Menanti Kecamatan Balik Bukit. Situs berupa dua lahan pertanian terpisah yang masing-masing dikelilingi siring. Lahan pertama luas 1 ha diperoleh tinggalan arkeologis berupa dua batuan yang disebut Batu Ikhau, yaitu batuan pasirandan satu lagi berupa batu berbahan andesit. Batu Ikhau diyakini masyarakat setempat sebagai tempat penyembelihan perempuan cantik untuk persembahan Dewa (Rusyanti, 2014). Jejak parit pada situs ini terlihat membatasi denah lahan situs persegi empat dengan saluran menuju Way Rubok di sebelah selatan (Gambar 3).

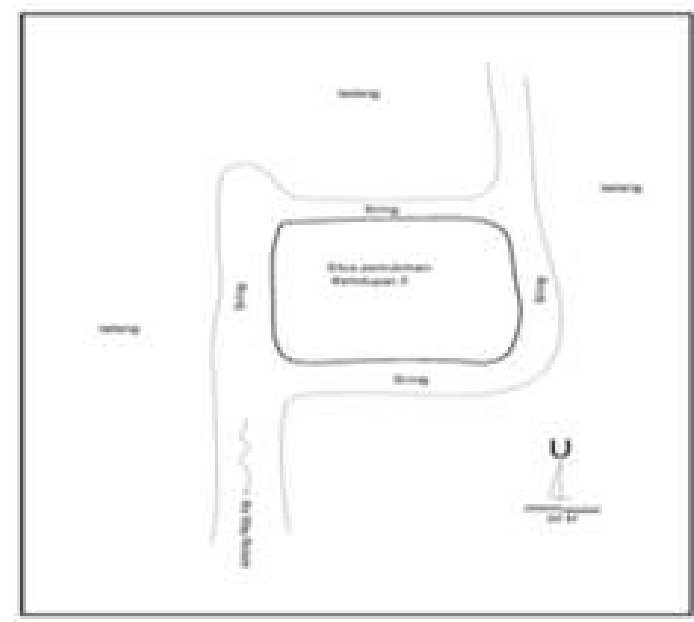

Gambar 3. Denah Situs Kehidupan 1 dan 2 dan foto lahan menurun (parit) sebagai pembatas lahan (Sumber: Dokumentasi Balai Arkeologi Jawa Barat, 2014).

\section{Situs Sukarame (Batu Raja, Punjung, Puncak, Negeri Ratu).}

Keempat situs berada di Desa Sukarami dengan jarak antar situs antara $0.5-2 \mathrm{~km}$. Empat situs berada pada posisi berderet barat-timur. Situs Batu Raja merupakan situs paling barat dari keempat situs yang ada di Sukarami berada di wilayah Pemangku Sukarami Induk, Desa Sukarami. Topografi situs bergelombang terletak di tepi sungai Way Robok. Terdapat 4 lokasi sebaran artefak arkeologi yaitu Situs Batu Raja 1, 2, 
3, dan 4 yang jaraknya relatif berdekatan dengan siring yang dangkal. Artefak yang ditemukan berupa fragmen keramik, tembikar, dan umpak batu (Rusyanti et al., 2018). Siring atau parit terlihat di sebelah selatan membentang dari barat ke timur dengan lebar dan kedalaman yang sama, yaitu $20-40$ meter.

Indikasi mengenai adanya permukiman kuno berparit di Lampung Barat sudah mulai muncul pada penelitian di tahun 1994, 1995 dan 2009. Berdasarkan penggambaran bentuk permukiman, diketahui bahwa lokasi situs Tanjung Raya dan Hujung Langit memiliki karakteristik yang sama, yaitu bidang lahan yang dikelilingi siring atau parit yang dalam dan terjal dengan kedalaman sekitar 12-25-meter dan lebar sampai dengan 40 meter. Dataran yang lebih rendah tersebut merupakan tanah subur karena merupakan daerah tadah hujan dan resapan air. Resapan air tersebut berasal dari pohon-pohon bambu diatasnya yang dahulunya sangat lebat dan berlapis-lapis. Ketika hujan air memenuhi parit tersebut sehingga seringkali disebut sebagi mata air. Di Situs Tanjung Raya parit tersebut difungsikan untuk lahan sawah tetapi di Hujung Langit masih berupa jurang dan masih didiami oleh hewan seperti monyet. Siring-siring atau parit tersebut diduga berfungsi sebagai pembatas, benteng pertahanan dan sekaligus sebagai mata air dan saluran pembuangan karena alurnya menuju aliran Way Rubok di sebelah selatan situs.

Tipologi bentuk permukiman dengan parit keliling dijumpai pula pada penelitian di tahun 2014. Bentang lahan dengan ciri dikelilingi siring dan sebaran fragmen keramik dan tembikar masih menjadi indikasi utama. Perbedaanya pada keenam permukiman kuno yang ditemukan, yaitu di Pulau Pinang, Batu Putih (Rusyanti, Laili, Hardikusmana, \& Amir, 2012), Situs
Kehidupan, Kawasan Negeri Ratu, Batu Raja yang termasuk kelompok wilayah kecamatan Sukau (Rusyanti, 2014), bentukbentuk siring yang ada tidak begitu terjal dibandingkan Situs Tanjung Raya dan Hujung langit. Siring-siring yang ada berkisar kedalaman antara 2-7-meter dan lebar 6-12-meter demikian pula dengan luas lahan yang relatif lebih kecil dibandingkan kedua situs sebelumnya.

Bentuk-bentuk permukiman dengan tipe benteng tanah dan parit juga dijumpai di DAS Sekampung dari hulu hingga hilir. Ukuran gundukan tanah ini bervariasi antara 2-6 meter, lebar parit rata-rata 2-7 meter, dan dalam parit ada yang mencapai 12 meter. Pada umumnya benteng-benteng ini ditemukan pada daerah yang mempunyai bentuk morfologi landai. Selain tinggalan berbentuk fitur, di situs-situs tersebut juga ditemukan tinggalan lainnya seperti artefak maupun ekofak. Sepintas gundukan tanah dan parit ini seakan-akan membentuk batas antara satu areal dengan areal lainnya. Di dalam ataupun diluar areal gundukan tanah dan parit sering dijumpai fitur seperti punden, gumuk, dolmen, batu lumpang, batu berjajar, komplek menhir, makam dan sebagainya sedangkan artefak yang ditemukan misalnya porselen, tembikar, manik-manik, alat batu dan lain-lain Situs-situs tersebut, yaitu Situs Gelombang, Situs Pejambon, Situs Pugung Raharjo, Situs Gedig, Situs Parigi, Situs Meris, Situs Cicilik, dan Situs Benteng Sari. Secara umum benteng-benteng tanah tersebut ada yang merupakan bentukan alami mengikuti kontur aslinya dan ada juga yang buatan (R.r. Triwurjani, 2010: 554).

\section{Asumsi dan Dugaan Sementara}

Munculnya pola umum berupa permukiman berparit di dua wilayah DAS, 
yaitu DAS Way Semangka dengan kelompok situs-situs Liwanya dan permukiman berparit di DAS Way Sekampung dilihat dari topografinya merupakan dua bentang alam yang sangat berbeda. Liwa merupakan wilayah dataran tinggi dan pegunungan yang merupakan wilayah dari rangkaian pegunungan Bukit Barisan yang membentang dari Aceh hingga Tanggamus (Highland). Lapisan tanah dan batuan yang terdapat di wilayah Liwa umumnya berasal dari endapan material gunung api yang membentuk perbukitan dan lembah dengan dominasi lapisan tuf pasiran yang lepas (moderate loose) di sebelah utara, dan lapisan tanah residu hasil lapukan material vulkanik dengan plastisitas dan kompresitas yang cukup tinggi di wilayah selatan (Anwar. et.al., 1994). Berdasarkan pengukuran umur batuan, Tuf Ranau yang diambil dari daerah

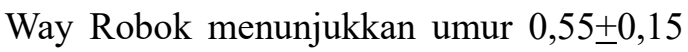
Ma, (Bellier et al., 1999), sedangkan menurut Natawijadja et al., 2017, batuan ini berumur 33.000 tahun yang lalu.

Secara geologi wilayah Liwa terletak pada zona patahan Sumatera (Anwar, et.al., 1994:1) yang berupa lajur retakan membentang dari Teluk Semangko di Selatan hingga lembah Aceh di Utara. Lajur ini membentuk segmen-segmen terban (graben) di antaranya Lembah Suoh, Antai, lembah Liwa, Way Wurkuk dan Kaldera Ranau (Bemmelen, 1949: 24-25). Sesar Sumatera merupakan sesar mendatar yang terbentuk sebagai akibat dari tumbukan lempeng yang miring (oblique) (Sieh dan Natawidjaja, 2000 dalam Aribowo 2016). Aktivitas sesar mendatar membentuk cekungan yang berpengaruh terhadap kondisi geomorfologi yang meliputi lembah sesar, kolam sesar ( $s a g$ pond), gawir sesar, bukit sesar (shutter ridge) yang membatasi aliran, dan sungai terputus (beheaded stream) (Burbank \&Anderson,
2012:Aribowo, 2016). Jejak-jejak patahan tersebut merupakan kolam-kolam mata air yang disebut sebagai siring atau parit yang mengelilingi situs sehingga akan tampak seperti pulau yang dikelilingi air (pepulau). Parit-parit alami bentukan sesar tersebut tampak jelas di Situs-situs di Liwa pada umumnya di selatan aliran Way Rubok.

Sedangkan DAS Way Sekampung berada diwilayah dataran rendah Lampung (lowland). Wilayah ini juga sekaligus merupakan wilayah dataran banjir (floodplain). Aliran Sungai Sekampung terbendung oleh Plato basalt Sukadana yang terbentuk sejaka masa pleisosen awal sehingga memicu beralihnya aliran ke tenggara yang berakibat pada terbentuknya cekungan, daerah banjir, dan rawa yang luas, salah satunya Rawa Sragi (Wurjani, 2010: 30). Jika dipetakan, pola situssitus yang berada di Liwa dan Sekampung akan berkorelasi dengan bentukan parit dengan kecenderungan yang berbeda. Paritparit di Liwa dominan merupakan parit alami sedangkan parit-parit di Sekampung diindikasi tidak semuanya alami ada beberapa merupakan parit buatan. Jika disandingkan dengan topografi wilayahnya yang rawa banjir, diduga parit-parit di Sekampung lebih sengaja dibuat untuk beradaptasi dengan banjir daripada hanya sebatas pilihan lokasi yang subur saja yang cenderung terlihat di Liwa. Kecenderungan parit-parit buatan diduga ditemukan pula di situs-situs lainnya terutama di wilayah dataran rendah, termasuk situs-situs di wilayah Tulangbawang, meskipun hal tersebut masih membutuhkan analisis lebih lanjut.

\section{Jejak Migrasi Austronesia Jalur Barat?}

Parit menurut Cambridge Dictionary adalah saluran terbuka yang digali pada 
tanah dengan fungsi pada umumnya untuk menyalurkan air atau membagi lahan. Di Indonesia, penelitian mengenai situssitus berparit dalam skala makro, belum ditemukan. Keberadaan parit-parit kuno (moat) sebelumnya telah menjadi perhatian pada penelitian arkeologi di Situs Mae Nam Mun Valley, Thailand pada tahun 1940an. Pengamatan dengan Aerial Photography Interpretation (API) atau citra satelit di Nam Mun River Valley, suatu wilayah dengan sedimentasi floodplain di timur laut Thailand menemukan 82 titik situs berparit (moat). Hasil analisis memperlihatkan keberadaan situs-situs arkeologi hampir seluruhnya lebih berkorelasi dengan paleochannels daripada sungai yang ada sekarang selain ditemukan juga jejak patahan (fault). Simpulan sementara menyatakan bahwa bentuk, pola distribusi, dan arah perkembangan situs mengikuti karakteristik yang bersifat geostruktural yang sekaligus juga memengaruhi perubahan arah dan konektivitas jaringan parit dari waktu ke waktu (Boyd, Higham, \& McGrath, 1999). Hingga kini jumlah moat yang terindikasi melalui google earth bahkan bertambah hingga 146 yang diduga muncul sejak zaman besi (iron age) sekitar 500 SM-600 A.D dengan fungsi yang masih belum diketahui (Dougald J.W \& Scott, 2015).

Indikasi paleochannel berdekatan dengan situs arkeologi pernah ditemukan di situs-situs neolitik di Cibeureum sebagai bukti kehadiran masyarakat Austronesia pada 1400-1600 tahun yang lalu di wilayah Lebak, Banten (Nurul Laili, Anton Ferdianto, Unggul Prasetyo Wibowo, Amir, Y. Hardikusmana, Desril Riva Shanti, Dede Sumiyati, 2019). Meskipun berada di dataran alluvial dan berpotensi banjir, seperti halnya karakteristik di Mun Valley dan area DAS di Lampung, tetapi di situs-situs di DAS Cibeureum tersebut tidak ditemukan parit keliling sepertihalnya yang ada di Lampung. Sehingga disimpulkan sementara bahwa ada dan tidaknya parit tidak selalu berkaitan dengan kondisi wilayah yang rentan banjir. Atau dengan kata lain fungsi parit tidak harus sebagai drainase. Kedua data tersebut sangat menarik untuk ditelisik lebih jauh yaitu kaitan wilayah Thailand dengan kearkeologian di Indonesia. Dalam peta skema sebaran Austronesia diketahui terdapat dua jalur, yaitu jalur barat dan timur (Simanjuntak, 2017).

Jalur timur mereka bermula di Taiwan, Filipina, dan masuk melalui Sulawesi, wilayah yang kerap dijadikan patokan migrasi ideal Austronesia ke Indonesia sedangkan jalur migrasi Austronesia ke arah barat termasuk Tanah Gayo (Sumatera Utara), kemungkinan dari China selatan ke Thailand lalu masuk ke Sumatera bagian utara. Hal ini didasarkan atas temuan gerabah poles merah yang memiliki pola hias yang sama dengan gerabah di Situs Ban Chiang, Thailand (Wiradnyana, 2013: 36). Meskipun masih terlalu dini, dapatlah dikemukakan kecurigaan apakah perilaku pembuatan parit keliling di Lampung merupakan kesamaan perilaku penurut Austronesia yang hadir di wilayah Sumatera pada masa lampau yang mempunyai persamaan perilaku membuat parit sama halnya dengan yang ditemukan di situs Mun Nam Valley, Thailand. Pembuktian ini menarik untuk dilakukan mengingat masih mininnya penelitian mengenai jejak Austronesia di Lampung yang seringkali dikaitkan dengan jejak artefak neolitik, baik alat batu maupun tembikarnya yang juga masih terbatas. 


\section{SIMPULAN}

Penelitian jejak-jejak permukiman di dua DAS besar di Lampung, yaitu DAS Way Semangka dan DAS Way Sekampung telah menemukan bukti-bukti permukiman kuno dengan salah satu bentukan fitur yang menonjol, yaitu didapati parit atau siring yang mengelilingi permukiman. Parit-parit di Lampung Barat dominan merupakan bentukan alam sedangkan parit-parit di DAS Way Sekampung beberapa merupakan parit buatan. Diduga keberadaan parit alami dan buatan merupakan bentuk adaptasi dengan topografi lingkungan tempat hidup yang berbeda yaitu di dataran tinggi dan dataran rendah. Selain sebagai bentuk adaptasi, perilaku membuat parit keliling juga di jumpai di Thailand. Hal tersebut memunculkan dugaan adanya kaitan wilayah Lampung sebagai wilayah sebaran penutur Austronesia jalur barat yang juga melalui wilayah Thailand khususnya jalur barat yang dapat diverifikasi lebih lanjut.

\section{DAFTAR PUSTAKA}

Agus, Yondri, L., \& Saptono, N. (1995). Laporan Hasil Penelitian Lingkungan dan Tinggalan Arkeologis di Situs Klasik Hara Kuning, Kabupaten Lampung Barat. Propinsi Lampung. Bandung.

Anwar Herryzal. (1994). Proceeding Ekspose Ilmiah Puslitbang Geoteknologi LIPI. Karakteristik Enjinering Lapisan Tufa Pasiran Dan Tanah Residu Di Daerah Liwa Dan Sekitarnya, 1-9. Puslitbang Geoteknologi LIPI.

Bellier, O., Bellon, H., Sébrier, M., Sutanto, \& Maury, R. C. (1999). K-Ar age of the Ranau Tuffs: Implications for the Ranau caldera emplacement and slippartitioning in Sumatra (Indonesia). Tectonophysics, 312(2-4), 347-359.
https://doi.org/10.1016/S00401951(99)00198-5

Bemmelen, R. W. van. (1949). The Geology of Indonesia Vol.IA. The Hague Netherlands: Martinus Nyhoff.

Boyd, W. E., Higham, C. F. W., \& McGrath, R. J. (1999). The Geoarchaeology of Iron Age"Moated" Sites of the Upper Mae NamMun Valley, N.E. Thailand. I:Palaeodrainage, Site- LandscapeRelationships and the Origins of the "Moats." Geoarchaeology An International Journal, 14(7), 675-716.

D.W.Burbank, R. . A. (2012). Tectonic Geomorphology. UK: WileyBlackwell.

Damais, L. C. (1995). Epigrafi dan Sejarah Nusantara Pilihan Karangan LouisCharles Damais. Jakarta: Pusat Penelitian dan Dokumentasi EFEO Jakarta.

Dougald J.W, O., \& Scott, G. (2015). Moated sites of the Iron Age in the Mun River Valley, Thailand: New discoveries using Google Earth. ELSEVIER: Archaeological Research in Asia, 3(JUly), 9-18. https://doi.org/https:// doi.org/10.1016/j.ara.2015.06.001

Endang Widyastuti. (2010). Kondisi Masyarakat Lampung Pada Masa Pengaruh hindu-Buddha. In W. R. Wahyudi (Ed.), Dari Masa Lalu ke Masa Kini: Kajian Budaya Materi, Tradisi, dan Pariwisata (pp. 17-26). Bandung: Alqa Print Jatinangor.

Endang Widyastuti. (2011). Masa Penghunian dan Pemanfaatan Situs Tanjung Raya Lampung. In S. Rahardjo (Ed.), Arkeologi: Pola Permukiman dan Lingkungan Hidup. Bandung: Alqa Print Jatinangor.

Laili, N. (2007). Permukiman Benteng Majapahit, Lampung Utara. In S. Rahardjo (Ed.), Permukiman, 
Lingkungan, dan Masyarakat (pp. 81-89). Bandung: Ikatan Ahli Arkeologi Indonesia (IAAI) Komda Jabar Banten.

Laili, N. (2008). Permukiman Bertradisi Megalitik di Situs Serampang, Rawa Sragi, Lampung. In K. Yulianto (Ed.), Dinamika Permukiman dalam Budaya Indonesia (pp. 31-44). Bandung: Ikatan Ahli Arkeologi Indonesia (IAAI) Komda Jabar Banten.

Nurul Laili, Anton Ferdianto, Unggul Prasetyo Wibowo, Amir, Y. Hardikusmana, Desril Riva Shanti, Dede Sumiyati, M. A. (2019). Sebaran Spasial Situssitus neolitik di DAS Cibeureum Kabupaten Lebak Bukti Sebaran Penutur Austronesia. Bandung.

R.r. Triwurjani. (2010). Adaptasi Komunitas Megalitik di DAS Sekampung Provinsi Lampung. In E. S. Hardiati \& R. r. Triwurjani (Eds.), Pentas Ilmu di Ranah Budaya: Sembilan Windu Prof.Dr. Edi Sedyawati (p. 575). Jakarta: Pustaka Larasan.

Rusyanti. (2012). Keruangan Situs Tanjung Raya Lampung Barat. In H. O. Untoro (Ed.), Arkeologi Ruang: Lintas Waktu sejak Prasejarah hingga Kolonial di Situs-situs Jawa Barat dan Lampung (pp. 143-158). Bandung: Alqa Print Jatinangor.

Rusyanti. (2014). Permukiman Kuno di Sekitar Situs Tanjung Raya dan Hujung Langit Kecamatan Sukau Kabupaten Lampung Barat. Laporan Penelitian. Bandung.

Rusyanti, Laili, N., Hardikusmana, Y., \& Amir. (2012). Permukiman Klasik di Situs Tanjung Raya Kecamatan Sukau Kabupaten Lampung Barat. Laporan Penelitian. Bandung.

Rusyanti, Purwoarminta, A., Krama, A. ., \& Widyastuti, E. (2018). Lansekap Arkeologi Situs-situs di DAS Way
Semangka Lampung Barat. Laporan Penelitian. Bandung.

Saptono, N. (2000). Pola dan Perkembangan Permukiman di Sepanjang Way Tulangbawang. In E. Saringendyanti (Ed.), Kronik Arkeologi: Perspektif Hasil Penelitian Arkeologi di Jawa Barat, Kalimantan Barat, dan Lampung (pp. 144-166). Jakarta: Pusat Penelitian Arkeologi Nasional.

Sarjiyanto. (2007). Model Perkampungan Situs Tepi Sungai di Lampung Tengah: Sebuah Hipotesis. In Permukiman, Lingkungan, dan Masyarakat (pp. 1-16).

Sieh, K., \& Natawidjaja, D. (2000). Neotectonics of the Sumatran fault, Indonesia. Journal of Geophysical Research, 105(B12), 28295. https:// doi.org/10.1029/2000JB900120

Simanjuntak, T. (2017). The Western Route Migration: A Second Probable Neolithic Diffusion to Indonesia. In et. al Philip J. Piper (Ed.), New Perspectives in Southeast Asian and Pacific Prehistory (pp. 201-2011). Canberra: Australian National University Press.

\section{HASIL DISKUSI}

\section{Pertanyaan}

\section{Eko Punto Hendro}

Apakah mungkin parit-parit tersebut memiliki makna simbolik?

\section{Budianto Hakim}

Di Sulawesi menemukan parit yang berkonteks dengan benteng pertahanan. Berdasarkan tokoh masyarakat dalam penelitian di sana, parit memiliki dua fungsi meliputi pengairan dan tempat persembunyian ketika terdesak. 
Mungkin bisa juga dilihat situs berparit di Benteng Cenrana, Kabupaten Bone Sulawesi Selatan barangkali mempunyai kemiripan?

\section{Nanang Saptono}

Paleochannel yang ada di Thailand itu, apakah seperti danau tapal kuda (oxbow lake?) kalo seperti itu, di Tulangbawang sepertinya banyak

\section{Jawaban}

1. Belum tau karena ini baru identifikasi awal. Parit dapat juga bermakna simbolik jika terlihat adanya keteraturan dan pola yang selaras dengan dogma atau konsep religinya, seperti misalnya konsep mikro dan makro kosmos pada
Hindu-Buddha akan tetapi jikapun demikian, pemaknaan juga perlu memperhatikan sumber sekunder dan sumber lainnya yang mendukung untuk memboboti sudut pandang teori mengenai pemaknaan yang akan digunakan nantinya

2. Jika situs tersebut berasal dari masa Islam dapat juga dilihat sebagai perbandingan mengingat konteks masa parit di Lampung ini juga masih belum jelas, kapan dibuatnya sedangkan data kronologi relatif yang ada hingga saat ini permukiman berparit memiliki rentang kronologi yang panjang sejak $10-19 \mathrm{M}$

3. Informasi yang menarik. Perlu penelitian geoarkeologi untuk mengkonfirmasinya. 